Indexed by

\section{Scopus}

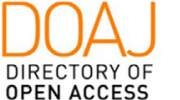

OPEN ACCESS

JOURNALS

Crossref

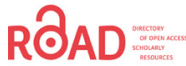

KOBSON

\section{Sugiarto Sugiarto}

Universitas Syiah Kuala, Department of Civil Engineering, Banda Aceh, Indonesia

\author{
Heru Fahlevi \\ Universitas Syiah Kuala, De- \\ partment of Accounting, Banda \\ Aceh, Indonesia
}

\author{
Ashfa Achmad \\ Universitas Syiah Kuala, \\ Department of Architecture \\ and Planning, Banda Aceh, \\ Indonesia
}

Lia Fajri

Universitas Syiah Kuala, Department of Civil Engineering, Alumni, Banda Aceh, Indonesia

\section{Tomia Miwa}

Nagoya University, Institute of Materials and Systems for Sustainability, Nagoya, Japan

Key words: service quality, public transport, preference data, IPA, Indonesia doi:10.5937/jaes0-27957

Cite article:

Sugiarto, S., Fahlevi, H., Achmad, A., Fajri, L., Miwa, T. (2021) THE RELATIVE IMPORTANCE OF BUS SYSTEM'S PERCEIVED SERVICE QUALITY (PSQ) ATTRIBUTES AMONG PUBLIC AND PRIVATE MODE USERS IN INDONESIA, Journal of Applied Engineering Science, 19(3) 600-609, DOI:10.5937/jaes0-27957 


\title{
THE RELATIVE IMPORTANCE OF BUS SYSTEM'S PERCEIVED SERVICE QUALITY (PSQ) ATTRIBUTES AMONG PUBLIC AND PRIVATE MODE USERS IN INDONESIA
}

\author{
Sugiarto Sugiarto ${ }^{1}$, *, Heru Fahlevi', Ashfa Achmad ${ }^{3}$, Lia Fajri", Tomia Miwa ${ }^{5}$ \\ ${ }^{1}$ Universitas Syiah Kuala, Department of Civil Engineering, Banda Aceh, Indonesia \\ ${ }^{2}$ Universitas Syiah Kuala, Department of Accounting, Banda Aceh, Indonesia \\ ${ }^{3}$ Universitas Syiah Kuala, Department of Architecture and Planning, Banda Aceh, Indonesia \\ ${ }^{4}$ Universitas Syiah Kuala, Department of Civil Engineering, Alumni, Banda Aceh, Indonesia \\ ${ }^{5}$ Nagoya University, Institute of Materials and Systems for Sustainability, Nagoya, Japan
}

Importance-Performance Analysis (IPA) is a common approach usually applied in examining public satisfaction and has been adopted in the transportation sector to measure the quality of service provided by the public transport system. This study, therefore, investigated the relative important service quality attributes of bus systems among both public and private modes of transportation users in Banda Aceh in Indonesia. An urban bus system known as the "Trans Koetardja" was used as a case study and a questionnaire designed based on preference survey was applied. A total of 200 samples comprising of 100 bus users and 100 private mode users including cars and motorcycles were used for the preliminary study. Moreover, the IPA approach was used to evaluate the Trans Koetaradja service quality attributes based on importance and performance classification. The quadrant grid plot showed the need for the operators to allocate their resources towards improving their services by considering (a) an improvement in bus stop facilities, (b) enhancement in the route and accurate timetable, and (c) shortening bus travel time and waiting time in the bus stop.

Key words: service quality, public transport, preference data, IPA, Indonesia

\section{INTRODUCTION}

Modern personal mode of transportation such as cars and motorcycles generate transport-related problems due to traffic congestion. This further leads to several externalities including unwarranted travel times, air pollution, unnecessary energy consumption, and frustration while driving in Jakarta (capital of Indonesia) [1-3]. These are found to be prevalent in Banda Aceh city [4,5], the provincial capital of Aceh in Indonesia due to the unexpected growth of car and motorcycle usage as well as the significant trip generated by motorcyclists [6]. Therefore, the need for the government to act intentionally towards overcoming motorization-related problems. The city center of Banda Aceh, like several other growing cities in Indonesia, is affected by the impecunious public transport services which are reflected in lower service quality, lack of safety for passengers, and inefficient capacity. As previous study noticed that congestion-manifested problems have also extended to the city of Banda Aceh as extraordinary growth in motorization has taken place [7]. As consequence, the government of Aceh needs to act strategically to deal with motorization related problems. To deal with the private mode dependency, the government have designed a proposal for the bus reform policy. Furthermore, the government has reformed the bus system to deal with the current unreliable bus services by replacing the conventional urban public transport with a more convenient system known as the "Trans Koetaradja". This involves the use of new technol- ogy in modern 60-passenger buses which are equipped with an air conditioner to ensure more comfortability. The Trans Koetaradja is currently under trial and operated free of charge in running corridors with the plan to upgrade the BRT system after it has successfully been tried [5,7-9].

Previous studies have demonstrated the central issue in any public transport planning and operation to be the provision of a better level of service for all users by the administrator/operator to maintain demand and encourage new users to switch from private to public transit. A crucial issue of any urban bus operators must be to deliver a sufficient quality of service for passengers, as it could maintain current users and possibly to attract new passengers. Thus, the objective to reducing private mode dependency by switching mode from private (car and motorcycle) to public mode (bus) could be obtained. Recent studies have been attempted on quantifying of perceived quality of service by passengers to distinguish the most probable influencing factors of service quality attributes. According to $[7,8,10]$, public acceptance for the proposal of Trans Koetaradja as new system of urban public transport in Banda Aceh city was found to be significantly high but the people are unable to make use of it effectively due to its limited routes. This means that there is a need for public transport administrators to classify the elements of service quality considered to be pertinent to public/users and use detailed strategic and 
operational policies to attract new users.

Previous studies concerning to the quality of service and passenger satisfaction have been systematically investigated in several developed cities over the globe, amongst them is De Oña et al [11] used simultaneous regression equations regarding satisfaction with the busline (service encounter) being used and with the system (global), correcting for heterogeneity in all the satisfaction constructs via the SEM-MIMIC approach. They found that the most critical variable for service encounter satisfaction is frequency/waiting time while global satisfaction is tangibles/image including satisfaction. De Oña et al [12] implemented cluster analysis and SEM to identify the most important service quality attributes. Furthermore, Javid et al [13] investigated the relationships between people's attitudes on service quality attributes of private car and public transport. They argued that social and personal dimensions of public transport should have equal importance, and the improvement in service quality of public transport needs to integrate with mobility restrictions on car use for effective change of travel behavior. Globally, there are intensive studies that attempt to investigate the satisfaction of public transport users for instance research done by [12-18] proposed a different approach was applied by previous works to evaluate service quality in the public transport sector. Moreover, the IPA method formerly proposed by [19] has been widely used to analysis sustainable tourism initiatives based on the resident perspective [20]. In public transportation, it has been adopted to analyze the practical implementation of transit user satisfaction [12,21-23]. Meanwhile, the IPA and OLS multiple linear regression were compared by [18] to analyze the related elements of satisfaction for bus users in Bogota and found IPA to be a more easy and effective method.

Following the rationale that satisfaction and service quality in public transport while research on this issue has mainly accomplished developed word. The determinants of satisfaction and service quality in public transport have not been examined systematically, particularly from the perspective of Asian cities. The satisfaction in public transport in Indonesia has been measured in Bali [24], in Yogyakarta [21,22] and Bandung [25]. This suggests that there are very few studies on public transport satisfaction as Indonesia is an archipelago consisting of many medium-large cities with a complex urban transportation system due to high dependence on private modes. Furthermore, it is hypnotized that the determinants of service quality in Banda Aceh (the westernmost province of Indonesia) could differ from the result of the study in developed cities due to travel behaviors and social, and demographic characteristics of passengers.

Therefore, this study was conducted to investigate service quality attributes based on their importance and performance classification particularly from the perspective of an Indonesian medium sized cities with the population around 259,913 [7]. This preliminary study involved using revealed preference data collected using a Likert scale choice experiment in 2018 within the first corridor and the busiest urban arterial road connected between the city center and the oldest University in Aceh (Universitas Syiah Kuala). Furthermore, the simple approach of the Importance-Performance Analysis (IPA) was implemented to examine the relative important attributes of bus system service quality among public transport and private mode users. The remaining part of this paper is divided into several parts to describe the survey and data profiles, IPA estimation, discussion of results while the conclusions are presented at the end.

\section{MATERIALS AND METHODS}

\section{Materials}

The preference data were collected using stated choice questionnaires. The four-point Likert scale: 1 = strongly unsatisfied/importance to 4 = strongly satisfy/importance [1-3]. They used a four-point Likert scale instead of a five-point Likert scale to avoid neutral choice. They recognized that a neutral choice needs to avoid reducing the risk of the dominant choice by the respondent. The set of 15 public transport quality of services-related questions had ordinal responses, with respondents choosing ordinal responses from the four-point Likert scale, as characterized in Table 2. The study was conducted in 2018 with the targeted area being line 1 of Trans Koetaradja which is the first line used to connect the city center of Banda Aceh to the oldest university in Aceh, Syiah Kuala University as shown in Figure 1.

The targeted respondents were bus and private mode users including the commuters, commercial visitors, students, and employees in the studied area. Dealing with validity sample size gathered in this study, According to Jenkinds and Quintana-Ascencio [26] recommend that research based on regressions analysis has to use a sample size larger than 25. Moreover, Sekaran and Bougie [27] proposes the following rules of thumb for determining sample size: (1) sample sizes larger than 30 and less than 500 are appropriate for most research; (2) where samples are to be broken into subsamples (males/females, juniors/seniors, etc.), a minimum sample size of 30 for each category is necessary; (3) In mul-

Table 1: Summary of the RP survey

\begin{tabular}{|c|c|}
\hline Description & Detail \\
\hline The year of survey & 2018 \\
\hline Target location & $\begin{array}{c}\text { Line 1 Bus System "Trans } \\
\text { Koetaradja" of Banda Aceh, } \\
\text { Indonesia }\end{array}$ \\
\hline $\begin{array}{c}\text { Distribution sampling } \\
\text { method }\end{array}$ & $\begin{array}{c}\text { Direct interviews and collect- } \\
\text { ed by the enumerators }\end{array}$ \\
\hline $\begin{array}{c}\text { Sampling aggregation } \\
100 \text { samples (bus ridership) } \\
100 \text { samples (non-bus users/ } \\
\text { private mode users) }\end{array}$ \\
\hline Distribution & $\begin{array}{c}\text { Weekdays (75\%); Weekends } \\
(25 \%)\end{array}$ \\
\hline
\end{tabular}

Istraživanja i projektovanja za privredu ISSN 1451-4117 Journal of Applied Engineering Science Vol. 19, No. 3, 2021 
tivariate research including multiple regression analyses, the sample size should be several times (preferably ten times or more) as large as the number of variables in the study; and (4) As for simple experimental research with tight experimental controls (matched pairs, etc.), successful research is possible with samples as small as 10 to 20 in size.

Hair et al [28] mentioned that the normality of the dataset can have serious effects in small samples (fewer than 50 cases), but the impact effectively diminishes when sample sizes reach 200 cases or more. In terms of absolute size, researchers generally would not factor analyze a sample of fewer than 50 observations, and preferably the sample size should be 100 or larger. However, researchers have suggested much larger samples (200 and larger) as the number of variables and expected number of factors increases [28]. Therefore, 200 samples could valid enough for IPA analysis. To ensure the justification that this sample size is enough for a good representation of the targeted population, we checked required minimum sample size using Lemeshow formula [29] with confidence level at $95 \%=1.96$, estimates of the population maximum estimated $=0.5$ of passenger's population up to 214,560 per month (reported by provincial Department of Transport) and sampling error (alpha) = $10 \%$. The calculation of the sample size gave a minimum sample size of 96 respondents. A minimum sample size of 100 for each category including 100 passengers using buses and another 100 using private cars and motorcycles is considered in this study. Therefore, we assumed that the approximation sample size in this study could justify for a good representation of the targeted population and validity of this study.

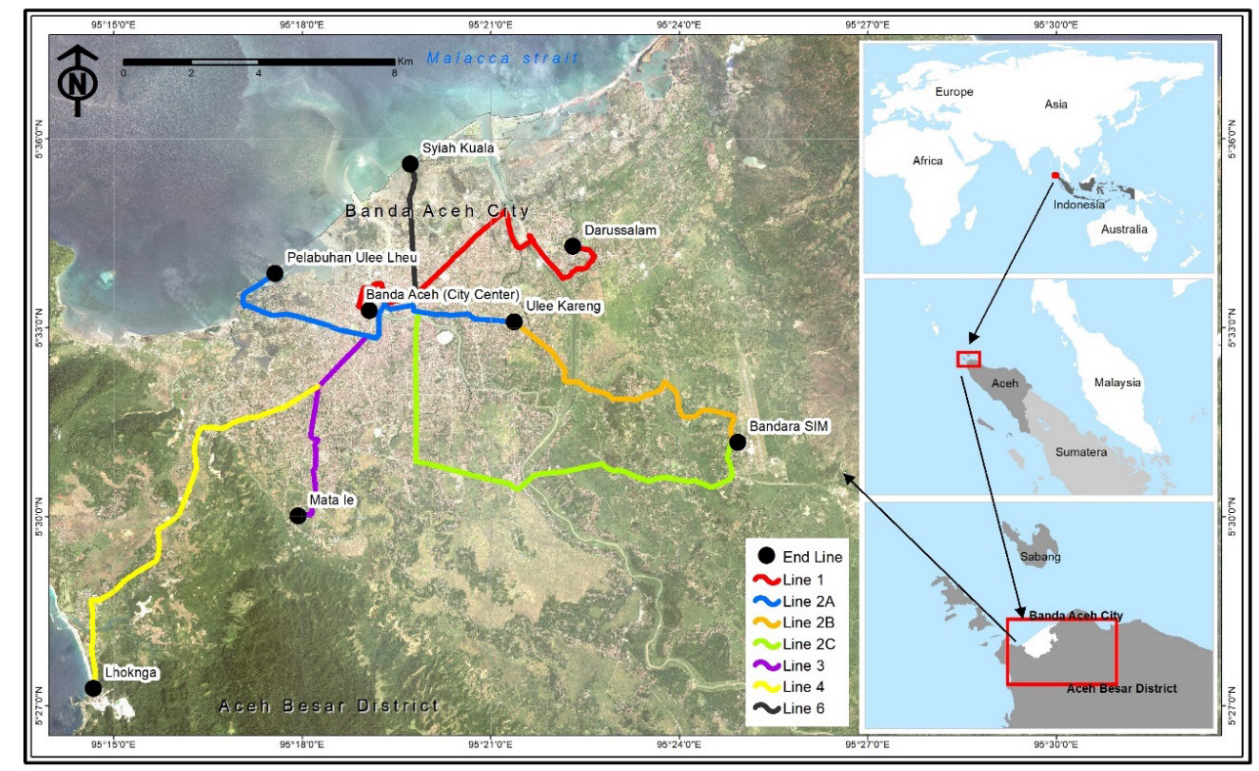

Figure 1: Banda Aceh city (map data (C) 2019 Google) and the studied area of Trans Koetaradja Line 1 in red color

Table 2: Question items related to the bus service satisfaction and importance measures

\begin{tabular}{|c|c|c|}
\hline Element ID & Element Description & ${ }^{*}$ Content of Element Question \\
\hline Q1 & Security 1 & Crime while inside the bus \\
Q3 & Security 2 & Crime while at the bus stop \\
Q4 & Safety & Feeling safe in the bus \\
Q5 & Convenience 1 & Bus cleanliness \\
Q6 & Convenience 2 & Convenience 3 \\
Q7 & Convenience 4 & Convenience while boarding the bus \\
Q8 & Convenience 5 & Bus capacity comfortability \\
Q9 & Accessibility & The convenience of bus facilities \\
Q10 & Punctuality 1 & The convenience of bus stop facilities \\
Q11 & Punctuality 2 & The ease with which the passengers reach the bus stop \\
Q12 & Equality & Ease of obtaining route and timetable of buses \\
Q13 & Time Regularity 1 & The accuracy of bus schedules \\
Q14 & Time Regularity 2 & Facilities for disabled and elderly people \\
Q15 & Tariff & Travel time within the bus stops \\
*using a 4-point Likert scale such as 1 to 4 (strongly unsatisfied/importance to strongly satisfy/importance)
\end{tabular}


A 4-point Likert scale which is represented by strongly unsatisfied to strongly satisfied or strongly unimportant to strongly important. Table 1 describes the RP survey which consists of the time the data were collected, survey location, sampling number, and distribution of the sample's information. The questionnaire was also designed to attain several bus system service elements as shown in Table 2 in the form of a paper-pencil direct interview in 2018 and distributed to 200 respondents with the results used for analysis.

Table 3 shows the respondent's socio-demographic and mobility attributes among bus and private mode users and more than $60 \%$ were surprisingly found to be female and over $75 \%$ were young people aged below 45 years. Moreover, primary school leavers and college graduates were observed to be predominant with most of them re- corded to be college/university students and employees. Most of the respondents for both private and bus transport system were earning below 3 million IDR per month per households [30] while $62 \%$ of the bus users has a motorcycle and approximately $30 \%$ has no vehicle and this means most of them are captive riders. Meanwhile, $76 \%$ of the private mode users have either a motorcycle or car while the remaining have both car and motorcycle. Approximately $50 \%$ of the bus users have no driver's license while more than $90 \%$ of the private mode users have a driver's license. Moreover, it was found that $76 \%$ of the bus users and $81 \%$ of private mode users had a compulsory trip to study in universities or to work as government or non-government employees on the day the questionnaires were distributed.

Table 3: Respondent's Socio-demographic distribution

\begin{tabular}{|c|c|c|c|}
\hline Item & Category & Bus User (Share) & Private Mode User (Share) \\
\hline \multirow{2}{*}{ Gender } & Male & $34(34 \%)$ & $29(29 \%)$ \\
\hline & Female & 66 (66\%) & $71(71 \%)$ \\
\hline \multirow{5}{*}{ Age } & 16 - 25 years & $52(52 \%)$ & $35(35 \%)$ \\
\hline & 26 - 35 years & $13(13 \%)$ & $14(14 \%)$ \\
\hline & $36-45$ years & $23(23 \%)$ & $32(32 \%)$ \\
\hline & 46 - 55 years & $9(9 \%)$ & $15(15 \%)$ \\
\hline & 56 years or more & $3(3 \%)$ & $4(4 \%)$ \\
\hline \multirow{4}{*}{ Education } & Primary School & $58(58 \%)$ & $46(46 \%)$ \\
\hline & College & $15(15 \%)$ & $17(17 \%)$ \\
\hline & University/Bachelor & $26(26 \%)$ & $35(35 \%)$ \\
\hline & University/postgraduate & $1(1 \%)$ & $2(2 \%)$ \\
\hline \multirow{5}{*}{ Monthly Income } & 1 million IDR or less & $37(37 \%)$ & $20(20 \%)$ \\
\hline & 1-1.9 million IDR & $34(34 \%)$ & $34(34 \%)$ \\
\hline & 2 - 2.9 million IDR & $20(20 \%)$ & $32(32 \%)$ \\
\hline & 3 - 3.9 million IDR & $7(7 \%)$ & $9(9 \%)$ \\
\hline & 4 million IDR or more & $2(2 \%)$ & $5(5 \%)$ \\
\hline \multirow{4}{*}{ Vehicle Ownership } & Has no vehicle & $29(295)$ & 0 \\
\hline & Has motorcycle & $62(62 \%)$ & $72(72 \%)$ \\
\hline & Has car & $1(1 \%)$ & $4(4 \%)$ \\
\hline & Has car and motorcycle & $8(8 \%)$ & $24(24 \%)$ \\
\hline \multirow{4}{*}{ Occupation } & College/University Student & $52(52 \%)$ & $35(35 \%)$ \\
\hline & Non-Government Employee & $30(30 \%)$ & $36(36 \%)$ \\
\hline & Government Employee & $7(7 \%)$ & $11(11 \%)$ \\
\hline & Housewife & $11(11 \%)$ & $18(18 \%)$ \\
\hline \multirow{2}{*}{ Driver's License } & Has a driver's license & $57(57 \%)$ & $94(94 \%)$ \\
\hline & Has no driver's license & $43(43 \%)$ & $6(6 \%)$ \\
\hline \multirow{4}{*}{$\begin{array}{l}\text { The purpose of traveling } \\
\text { on the day the question- } \\
\text { naire was distributed }\end{array}$} & Studying and lessons & $47(47 \%)$ & $35(35 \%)$ \\
\hline & Work & $29(29 \%)$ & $46(46 \%)$ \\
\hline & Shopping/Entertainment & $10(10 \%)$ & $9(9 \%)$ \\
\hline & Others traveling & $14(14 \%)$ & $10(10 \%)$ \\
\hline
\end{tabular}




\section{Methods}

Importance-Performance Analysis (IPA) is originally used to measure consumer's perceived performance and importance by plotting two dimensions of the quadrant to interpret data [19]. The quadrants were further classified by [31] into four categories which are "keep up the good work" (Q1), "possible overkill" (Q2), "low priority" (Q3) and "concentrate here" (Q4) as shown in Figure 2. Q1 was described to be representing the significant strengths and potential competitive advantages of the service and it contains well-performing and continuous investment elements. Q2 has low importance to customers but indicates high performing and also shows the possibility of inefficiency in utilizing resources. Q3 falls into the low priority grid with the elements reported to be as unimportant and not performing well and reflected in weakness and poor performance. Meanwhile, Q4 is regarded as the vital quadrant with its attributes measured to be underperforming and producing significant flaws and observed to have the substantial and highest priority in improving products or services.

The previously mentioned RP data was used to conduct IPA analysis to reveal the conformity level among bus service elements perceived by both the bus and private mode users using 4-point Likert scores to measure the attributes obtained from the survey. The mean values were later used to plot the two-dimensional IPA approach which was divided into four quadrants with the performance on the $y$-axis and importance on the $x$-axis.

The IPA results were graphically displayed on the two-dimensional grid and clustered into Q1, Q2, Q3, and Q4 labels based on the values of the discriminating thresholds after which a diagonal or iso-rating line was drawn 450 upward to distinguish the plot into separate areas [32,33]. This iso-rating line represents elements of products or services with an equality rating among importance and performance attributes. The analysis was later used to generate suggestions to develop marketing strategies.

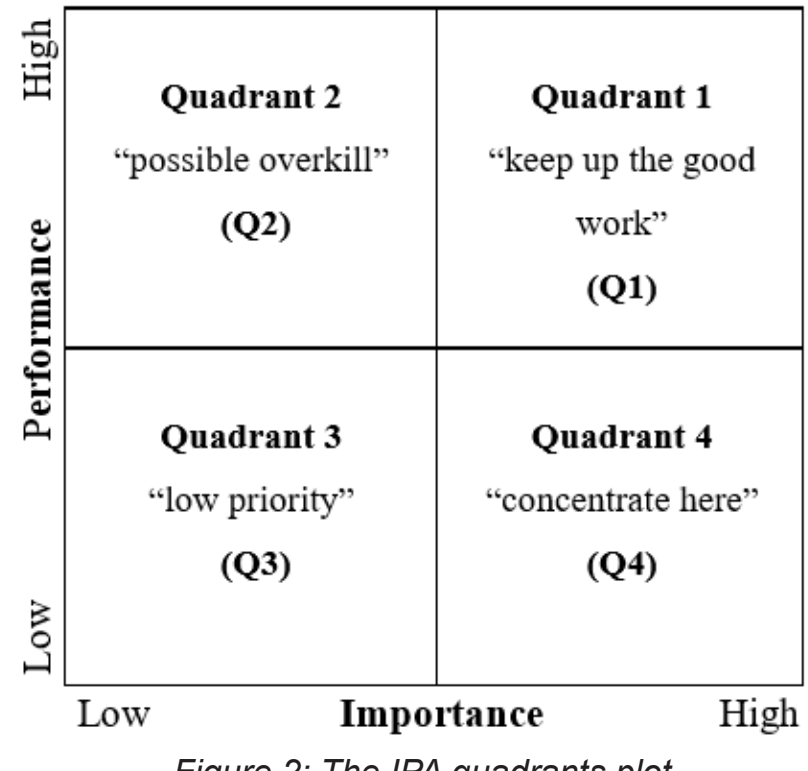

Figure 2: The IPA quadrants plot

Istraživanja i projektovanja za privredu ISSN 1451-4117

Journal of Applied Engineering Science Vol. 19, No. 3, 2021

\section{RESULTS AND DISCUSSION}

Prior to the IPA analysis, we conducted validity and reliability itemed in our instrument with number of samples used is 25 samples for each of category from passengers and private mode users. It is common to look at the reliability of instruments using statistical test in terms of Cronbach's alpha $[34,35]$. Cronbach alpha is commonly reported for the development of scales intended to measure attitudes and other affective constructs [35]. An indicator of alpha having a threshold or cut-off as an acceptable, sufficient or satisfactory level with normally seen as $>0.70$ [36] although some article more vaguely referred to the acceptable values of 0.7 or 0.6 [37]. In our study, several of the values calculated for Cronbach's alpha are range from $0.7-0.9$, this value is acceptable and considered as valid items to measure the quality of service of Trans Koetaradja bus.

Table 4 and Figure 4 showed the result of IPA analysis based on bus users and the mean of importance was found to be higher than the mean of satisfaction as observed in their values of 3.58 and 2.72 , respectively. These values represent intersection or thresholds to categorize the IPA grid into four quadrants and the conformity level was estimated to be $76.33 \%$. This, therefore, shows the bus users have moderate satisfaction in the current services. Figure 2 shows Q4 is measured as the vital quadrant with its attributes include being restrained from underperforming and being the foremost weakness and was also found to have the most substantial importance to improve Trans Koetaradja performance. The improvement efforts required to be considered include five service elements which are E8 (convenience 5/bus stop facilities, E10 (punctuality 1/route and timetable), E10 (punctuality 2/accuracy of timetable), E13 (time regularity $1 /$ travel time), and E14 (time regularity $2 /$ headway). This means punctuality, travel time, and waiting time are the primary attributes required to attract Trans Koetaradja ridership based on the possibilities of replacing the existing public transport which was observed to lack reliability in terms of punctuality, travel time, waiting time, and facilities or convenience with the new bus system. This result shows that the current bus has an unreliable quality of service and needs to improve to maintain current passengers and attract new users. As the conformity level was estimated to be $76.33 \%$ (moderate satisfaction), the bus operator needs to improve the satisfaction level through refinement of the bus's quality of services. This result also in line with the result of a study conducted in Lahore, Pakistan (an example of a developing city) done by [13]. They found that the attitudes of respondents are negative for public transport and positive for a private car. It means the people have negative perceptions regarding the image of existing public transport. These extracted factors of attitudinal aspects were used to evaluate their influence on behavioral intentions towards public transport.

Figure 3 further reveals some attributes of Trans Koetaradja have high performance and importance and clas- 
Table 4: The mean and conformity level of importance-performance elements by bus users

\begin{tabular}{|c|c|c|c|c|}
\hline Element ID & Element Description & $\begin{array}{c}\text { Mean of } \\
\text { performance }\end{array}$ & $\begin{array}{c}\text { Mean of } \\
\text { importance }\end{array}$ & Conformity level (\%) \\
\hline E1 & Security 1 (crime in the bus) & 3.10 & 3.37 & 91.99 \\
\hline E2 & Security 2 (crime in bus stop) & 3.07 & 3.58 & 85.75 \\
\hline E3 & Safety & 2.77 & 3.70 & 74.86 \\
\hline E4 & Convenience 1 (cleanliness) & 3.14 & 3.47 & 90.49 \\
\hline E5 & Convenience 2 (boarding the bus) & 3.37 & 3.64 & 92.58 \\
\hline E6 & Convenience 3 (bus capacity) & 3.47 & 3.69 & 94.04 \\
\hline E7 & Convenience 4 (bus facilities) & 3.11 & 3.67 & 84.74 \\
\hline E8 & Convenience 5 (bus stop facilities) & 2.51 & 3.69 & 68.02 \\
\hline E9 & Accessibility (Ease reach the bus stop) & 2.64 & 3.55 & 74.37 \\
\hline E10 & Punctuality 1 (route and timetable) & 2.28 & 3.69 & 61.79 \\
\hline E11 & Punctuality 2 (accuracy of timetable) & 2.09 & 3.70 & 56.49 \\
\hline E12 & Equality (disabilities and elderly) & 3.00 & 3.66 & 81.97 \\
\hline E13 & Time Regularity 1 (travel time) & 2.24 & 3.72 & 60.22 \\
\hline E14 & Time Regularity 2 (headway) & 1.84 & 3.76 & 48.94 \\
\hline E15 & Tariff & 2.22 & 2.82 & 78.72 \\
\hline \multicolumn{2}{|r|}{ Total } & 40.85 & 53.71 & 76.06 \\
\hline \multicolumn{2}{|r|}{ Mean } & 2.72 & 3.58 & 76.33 \\
\hline
\end{tabular}

sified under Q1 which is "keep up the good work". This quadrant indicates some of the elements to consider such as E2 (security 2 /crime in bus stop), E3 (safety), E5 (convenience 2/boarding the bus), E6 (convenience 3/bus capacity), E7 (convenience 4/bus facilities), and E12 (equality/disabled and elderly). The iso-rating line finally showed the overall elements performing above satisfaction to include E1 (security 1/crime in the bus), E4 (convenience 1/cleanliness), and E15 (tariff) compared to the remaining elements listed below the line as indicated in Figure 3. These influencing factors such as security/crime in the bus and convenience/cleanliness have shown significant attributes in determining passenger satisfaction. Previous study by Susilawati and Nilakusmawati [24] have argued that the dominant factor affecting public transport user satisfaction is safety and comfort, with the most influential variable is feeling concerned about the personal safety of users when on the bus in Bali, Indonesia. Furthermore, Hidayat [22] notified that the operator needs to improve the system by allocates resources on the following attributes a) keep punctuality, b) shorten waiting time in the bus stop, c)

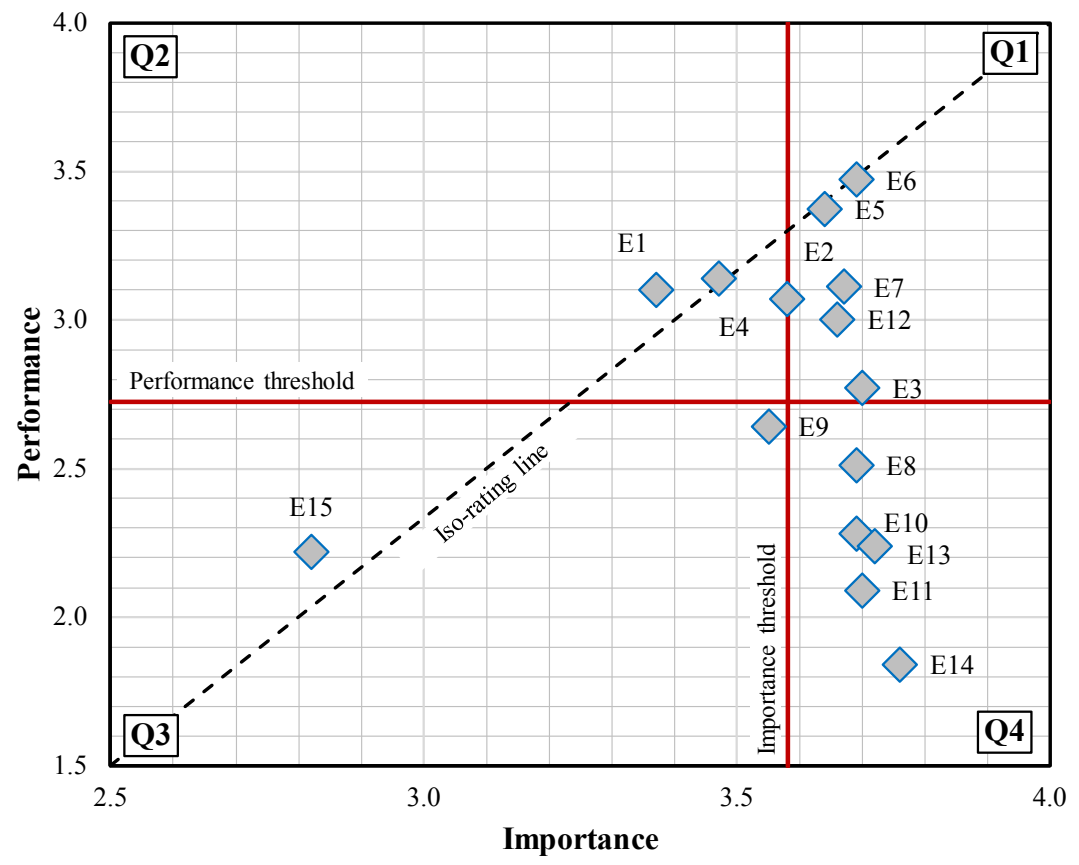

Figure 3: The IPA quadrants plot of importance-performance elements by bus users 
Table 5: The mean and conformity level of importance-performance elements by private mode users

\begin{tabular}{|c|c|c|c|c|}
\hline Element ID & Element Description & $\begin{array}{c}\text { Mean of } \\
\text { performance }\end{array}$ & $\begin{array}{c}\text { Mean of } \\
\text { importance }\end{array}$ & Conformity level (\%) \\
\hline E1 & Security 1 (crime in the bus) & 3.13 & 3.33 & 93.99 \\
\hline E2 & Security 2 (crime in bus stop) & 3.27 & 3.52 & 92.90 \\
\hline E3 & Safety & 3.43 & 3.66 & 93.72 \\
\hline E4 & Convenience 1 (cleanliness) & 3.16 & 3.66 & 86.34 \\
\hline E5 & Convenience 2 (boarding the bus) & 3.17 & 3.75 & 84.53 \\
\hline E6 & Convenience 3 (bus capacity) & 2.61 & 3.78 & 69.05 \\
\hline E7 & Convenience 4 (bus facilities) & 3.16 & 3.83 & 82.51 \\
\hline E8 & Convenience 5 (bus stop facilities) & 2.11 & 3.77 & 55.97 \\
\hline E9 & Accessibility (Ease reach the bus stop) & 2.65 & 3.68 & 72.01 \\
\hline E10 & Punctuality 1 (route and timetable) & 2.12 & 3.81 & 55.64 \\
\hline E11 & Punctuality 2 (accuracy of timetable) & 1.84 & 3.73 & 49.33 \\
\hline E12 & Equality (disabilities and elderly) & 3.11 & 3.7 & 84.05 \\
\hline E13 & Time Regularity 1 (travel time) & 2.49 & 3.91 & 63.68 \\
\hline E14 & Time Regularity 2 (headway) & 1.79 & 3.89 & 46.02 \\
\hline E15 & Tariff & 2.48 & 2.75 & 90.18 \\
\hline \multicolumn{2}{|r|}{ Total } & 40.52 & 54.77 & 73.98 \\
\hline \multicolumn{2}{|r|}{ Mean } & 2.70 & 3.65 & 74.66 \\
\hline
\end{tabular}

improve bus comfort, d) provide safety for child passenger, e) improve bus stop comfort, f) create new bus route to enlarge accessibility, and g) shorten bus travel time. Public transport user satisfaction has a positive and significant effect on the performance of public transport, any increase in public transport performance indicators will also influence the increase in satisfaction of users of public transport [21] and further the public transport sector shows increasing concern for a better understanding of the factors affecting service quality [23].
Table 5 and Figure 4 illustrate the IPA result for non-bus or private mode users and the same trend was observed with the bus users with the mean value of importance found to be substantially higher than satisfaction as indicated with 3.65 and 2.70, respectively. Meanwhile, the conformity level was slightly lower with $74.66 \%$ compared to the $76.33 \%$ recorded for the bus users, and this partially due to the non-extensive use of Trans Koetaradja buses by the private mode users. This, therefore, led to their likelihood of having lesser satisfaction compared to the main users.

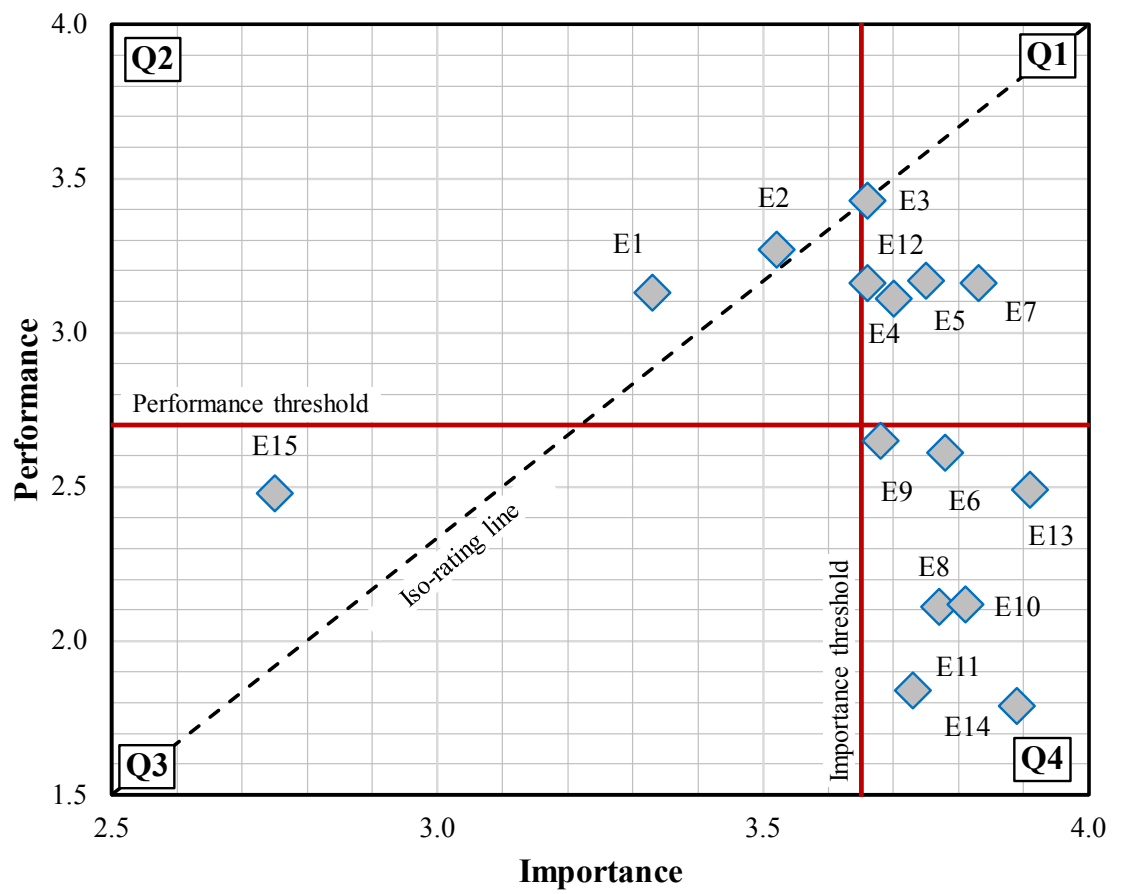

Figure 4: The IPA quadrants plot of importance-performance elements by private mode users 
The quadrants of the IPA grid are presented in Figure 4 and the most critical was indicated to be Q4 ("concentrate here"). This means the Trans Koetaradja operators need to consider the elements in this quadrant due to its importance to improving the bus performance by focusing on E9 (convenience 3/bus capacity), E6 (convenience 5 /bus stop facilities), E13 (accessibility/ease to reach the bus stop), E8 (punctuality 1/route and timetable), E10 (punctuality 2/accuracy of timetable), E11 (time regularity $1 /$ travel time), and E14 (time regularity 2 /headway). These results are also consistent with the IPA result from passengers' point of view which found punctuality, travel time, and waiting time (headway) to be important for Trans Koetaradja operators in improving the reliability of the system. The iso-rating line finally showed the overall elements to be considered include E1 (security 1/crime inside the bus), E2 (security 2/crime at the bus stop), and E15 (tariff) which are plotted above the line and considered important in satisfying the passengers. These are, however, like the perspectives of the bus users.

\section{CONCLUSIONS}

The IPA approach based on the quadrant grid plot implemented in this study showed the need for Trans Koetaradja operators to allocate their resources by considering important and performance attributes towards improving the bus performance. The mean value of importance elements was found to be higher than for satisfaction for both bus users which are the passengers and private mode users which are non-passengers. Moreover, the conformity level for private users was discovered to be slightly lower with $74.66 \%$ compared to the $76.33 \%$ recorded for bus users and these indicate moderate satisfaction in the bus service attributes. The IPA quadrant grid plot further showed there is a need to improve bus stop facilities, route, and timetable reliability, and to shorten bus travel time and waiting time at the bus stop. The IPA plot also indicated some attributes of Trans Koetaradja buses to be high performing and important and considered under "keep up the good work" quadrant. The elements recommended to be improved, therefore, include (a) security $2 /$ crime at the bus stop, (b) safety, (c) boarding facilities of the bus, (d) convenience $3 /$ bus capacity, (e) convenience 4/bus facilities, and (f) equality/ disabled and elderly people. The perceived service quality of the bus system based on the perspectives of both the bus and non-bus uses on the performance-importance elements was the focus of this study. The empirical findings of this study would be helpful for public transport operator in considering the appropriate attributes of public transport to allocate their resources in improving quality of service of the bus. This study is expected to provide insight for policymakers while considering bus quality of service constraints in enhancing the bus quality of service. This strategy could improve passenger and reducing negative perceptions regarding the image of existing public transport. Finally, the objective to maintain current users and possibly to attract new passengers by switch- ing mode from private (car and motorcycle) to public mode (bus) could be obtained.

The limitation of this study is that the sample size is drawn only from one bus line (the busiest line). As the operator has been operated five bus lines in 2020, there is an opportunity to increase the area of study and enhance the sample size to deal with the heterogeneity and comprehensively bus quality of service. Furthermore, this study may be necessary to extend for measure the service quality of the bus from the operator's perspectives or through the system encounter and this is expected to be the focus of future studies.

\section{ACKNOWLEDGMENTS}

The authors express their honest gratitude to all those that helped in this study. The authors also appreciate the Universitas Syiah Kuala for providing financial support in collecting data under Contract No. 523/UN11/SPK/ PNBP/2019 and the joint research program of the Institute of Materials and Systems for Sustainability, Nagoya University. The authors take responsibility for all the remaining oversight in this study.

\section{REFERENCES}

1. Sugiarto, S., Miwa, T., Sato, H., \& Morikawa, T. (2017). Explaining Differences in Acceptance Determinants Toward Congestion Charging Policies in Indonesia and Japan. Journal of Urban Planning and Development, 143(2), 04016033. https://doi. org/10.1061/(ASCE)UP.1943-5444.0000360

2. Sugiarto, S., Miwa, T., \& Morikawa, T. (2017). Inclusion of latent constructs in utilitarian resource allocation model for analyzing revenue spending options in congestion charging policy. Transportation Research Part A: Policy and Practice, 103, 36-53. https://doi. org/10.1016/j.tra.2017.05.019

3. Sugiarto, S., Miwa, T., \& Morikawa, T. (2020). The tendency of public's attitudes to evaluate urban congestion charging policy in Asian megacity perspective: Case a study in Jakarta, Indonesia. Case Studies on Transport Policy, 8(1), 143-152. https://doi. org/10.1016/j.cstp.2018.09.010

4. Saleh, S. M., Sugiarto, S., Hilal, A., \& Ariansyah, D. (2017). A study on the traffic impact of the road corridors due to flyover construction at Surabaya intersection, Banda Aceh of Indonesia. AIP Conference Proceedings 1903, 060005. https://doi. org/10.1063/1.5011559

5. Irvansyah, R., Sugiarto, S., Achmad, A., \& Fahlevi, H. (2020). Analysis of the Trans Koetaradja bus services considering latent variables of bus line services. IOP Conference Series: Materials Science and Engineering, 917, 012036. https://doi.org/10.1088/1757899X/917/1/012036 
6. Anggraini, R., Sugiarto, S., \& Pramanda, H. (2017). Factors affecting trip generation of motorcyclist for the purpose of non-mandatory activities. AIP Conference Proceedings 1903, 060011. https://doi. org/10.1063/1.5011565

7. Saleh, S. M., Sugiarto, S., \& Anggraini, R. (2019). Analysis on Public's Response Toward Bus Reform Policy in Indonesia Considering Latent Variables. The Open Transportation Journal, 13(1), 17-24. https://doi.org/10.2174/1874447801913010017

8. Saleh, S. M., Sugiarto, S., \& Salmannur, A. (2019). Attitudinal dataset for mediating the effects of public acceptance on bus reform scheme in a developing country context. Data in Brief, 25, 104035. https:// doi.org/10.1016/j.dib.2019.104035

9. Safitri, E., Sugiarto, S., Anggraini, R., Achmad, A., \& Fahlevi, H. (2020). Analysis on the effect of socio-economic and travel attributes to perceptions of the Trans Koetaradja quality of services. IOP Conference Series: Materials Science and Engineering, 917, 012038. https://doi.org/10.1088/1757899X/917/1/012038

10. Sugiarto, S., Saleh, S. M., Anggraini, R., \& Merfazi, M. (2019). Investigating public perceptions and its implication toward Trans Koetaradja policy considering latent motivation. IOP Conference Series: Materials Science and Engineering, 523, 012036. https:// doi.org/10.1088/1757-899X/523/1/012036

11. Allen, J., Muñoz, J. C., \& Ortúzar, J. de D. (2018). Modelling service-specific and global transit satisfaction under travel and user heterogeneity. Transportation Research Part A: Policy and Practice, 113, 509-528. https://doi.org/10.1016/j.tra.2018.05.009

12. De Oña, J., De Oña, R., \& López, G. (2016). Transit service quality analysis using cluster analysis and decision trees: A step forward to personalized marketing in public transportation. Transportation, 43(5), 725-747. https://doi.org/10.1007/s11116-015-9615-0

13. Javid, M. A., Okamura, T., Nakamura, F., Tanaka, S., \& Wang, R. (2016). People's behavioral intentions towards public transport in Lahore: Role of situational constraints, mobility restrictions and incentives. KSCE Journal of Civil Engineering, 20(1), 401-410. https://doi.org/10.1007/s12205-015-1123-4

14. Weinstein, A. (2000). Customer Satisfaction Among Transit Riders: How Customers Rank the Relative Importance of Various Service Attributes. Transportation Research Record: Journal of the Transportation Research Board, 1735(1), 123-132. https://doi. org/10.3141/1735-15

15. Chen, F.-Y., \& Chang, Y.-H. (2005). Examining airline service quality from a process perspective. Journal of Air Transport Management, 11(2), 79-87. https:// doi.org/10.1016/j.jairtraman.2004.09.002
16. Del Castillo, J. M., \& Benitez, F. G. (2013). Determining a public transport satisfaction index from user surveys. Transportmetrica A: Transport Science, 9(8), 713-741. https://doi.org/10.1080/18128602.20 11.654139

17. Machado-León, J. L., de Oña, R., Baouni, T., \& de Oña, J. (2017). Railway transit services in Algiers: Priority improvement actions based on users perceptions. Transport Policy, 53, 175-185. https://doi. org/10.1016/j.tranpol.2016.10.004

18. Rodriguez-Valencia, A., Rosas-Satizabal, D., \& Paris, D. (2019). Importance-Performance Analysis in Public Transportation: Methodological Revision for Practical Implementation. Transportation Research Record: Journal of the Transportation Research Board, 2673(2), 710-723. https://doi. org/10.1177/0361198118825125

19. Martilla, J. A., \& James, J. C. (1977). Importance-Performance Analysis. Journal of Marketing, 41(1), 77. https://doi.org/10.2307/1250495

20. Boley, B. B., McGehee, N. G., \& Tom Hammett, A. L. (2017). Importance-performance analysis (IPA) of sustainable tourism initiatives: The resident perspective. Tourism Management, 58, 66-77. https:// doi.org/10.1016/j.tourman.2016.10.002

21. Putra, A. A., Yamin, M., Riyanto, B., \& Mulyono, A. T. (n.d.). The Satisfaction Analysis for the Performance of Public Transport Urban Areas. 7.

22. Hidayat, N. (2018). Performance level analyses of public transportation using importance-performance analysis method. MATEC Web of Conferences, 147, 02001. https://doi.org/10.1051/matecco$\mathrm{nf} / 201814702001$

23. de Oña, J., \& de Oña, R. (2015). Quality of Service in Public Transport Based on Customer Satisfaction Surveys: A Review and Assessment of Methodological Approaches. Transportation Science, 49(3), 605-622. https://doi.org/10.1287/trsc.2014.0544

24. Susilawati, M., \& Nilakusmawati, D. P. E. (2017). Study on the factors affecting the quality of public bus transportation service in Bali Province using factor analysis. Journal of Physics: Conference Series, 855, 012051. https://doi.org/10.1088/1742$6596 / 855 / 1 / 012051$

25. Joewono, T., \& Kubota, H. (2007). User Perceptions of Private Paratransit Operation in Indonesia. Journal of Public Transportation, 10(4). https://doi. org/10.5038/2375-0901.10.4.5

26. Jenkins, D. G., \& Quintana-Ascencio, P. F. (21 Feb 20). A solution to minimum sample size for regressions. PLOS ONE, 15(2), e0229345. https://doi. org/10.1371/journal.pone.0229345 
27. Sekaran, U., \& Bougie, R. (2016). Research Methods for Business (Seventh edition). Wiley.

28. Hair, J. F. (2019). Multivariate data analysis (Eighth edition). Cengage.

29. Lwanga S. K., Lemeshow S., \& Organization W. H. (1991). Sample size determination in health studies: A practical manual. World Health Organization. https://apps.who.int/iris/handle/10665/40062

30. Putri, A., Sugiarto, S., Saleh, S. M., \& Basrin, D. (2020). Travel cost budget distributions among household life stages considering bus users in Banda Aceh. IOP Conference Series: Materials Science and Engineering, 933, 012012. https://doi. org/10.1088/1757-899X/933/1/012012

31. Sever, I. (2015). Importance-performance analysis: A valid management tool? Tourism Management, 48, 43-53. https://doi.org/10.1016/j.tourman.2014.10.022

32. Azzopardi, E., \& Nash, R. (2013). A critical evaluation of importance-performance analysis. Tourism Management, 35, 222-233. https://doi.org/10.1016/j. tourman.2012.07.007

33. Ziegler, J., Dearden, P., \& Rollins, R. (2012). But are tourists satisfied? Importance-performance analysis of the whale shark tourism industry on Isla Holbox, Mexico. Tourism Management, 33(3), 692-701. https://doi.org/10.1016/j.tourman.2011.08.004
34. Cronbach, L. J. (n.d.). Coefficient alpha and the internal structure of tests. 38.

35. Taber, K. S. (2018). The Use of Cronbach's Alpha When Developing and Reporting Research Instruments in Science Education. Research in Science Education, 48(6), 1273-1296. https://doi. org/10.1007/s11165-016-9602-2

36. O’Neill, M. A., \& Palmer, A. (2004). Importance $\square$ performance analysis: A useful tool for directing continuous quality improvement in higher education. Quality Assurance in Education, 12(1), 39-52. https://doi. org/10.1108/09684880410517423

37. Van Griethuijsen, R. A. L. F., van Eijck, M. W., Haste, H., den Brok, P. J., Skinner, N. C., Mansour, N., Savran Gencer, A., \& Bou Jaoude, S. (2015). Global Patterns in Students' Views of Science and Interest in Science. Research in Science Education, 45(4), 581-603. https://doi.org/10.1007/s11165-014-9438-6 